\title{
Peptide composition, oxidative and insecticidal activities of nectar from flowers of Spathodea campanulata P. Beauv
}

\author{
Valter H.M. Santos ${ }^{a}, *$, Igor O. Minatel ${ }^{a}$, Paulo C. Reco ${ }^{b}$, Alexandre Garcia ${ }^{c}$, \\ Giuseppina P.P. Lima ${ }^{\mathrm{a}}$, Regildo M.G. Silva ${ }^{\mathrm{d}}$ \\ a Universidade Estadual Paulista (UNESP), Instituto de Biociências de Botucatu, Departamento de Bioquímica, Botucatu, Brazil \\ ${ }^{\mathrm{b}}$ Instituto Agronômico (IAC), Campinas, Brazil \\ ${ }^{\mathrm{c}}$ Tropical Melhoramento Genético (TMG), Cambé, Brazil \\ d Universidade Estadual Paulista (UNESP), Departamento de Biotecnologia, Laboratório de Fitoterápicos, Assis, Brazil
}

\section{A R T I C L E I N F O}

\section{Article history:}

Received 3 October 2016

Received in revised form 1 December 2016

Accepted 18 December 2016

Available online 23 December 2016

\section{Keywords:}

Insecticidal tests

Nectar

Oxidant tests

Protein characterization

Peptides

Proteomics

\begin{abstract}
A B S T R A C T
The growing demand for food has intensified the search for compounds of plant origin to protect field crops from predators and pathogens, as these compounds have less environmental impact and are considered healthier than synthetic compounds. Among plant species with insecticidal activity, Spathodea campanulata has been identified as a potential source of insecticidal compounds. Therefore, in this study we verified the insecticidal effect of nectar from $S$. campanulata against three different insects. In addition, the oxidant activity of nectar and proteomic assay were conducted to identify the insecticide potential. Both gross and dialyzate nectar showed a promising toxic effect against Euschistus heros (Fabr.), Helicoverpa zea (Boddie) and Anticarsia gemmatalis (Hübner) insects. According to oxidant tests, non-denatured nectar showed a higher oxidant activity than denatured nectar, in both albumin degradation and TBARS tests. SDS-PAGE and 2D-PAGE were used to characterize the nectar proteins, revealing 13 spots that were compatible to either proteins or peptides. The most relevant spots were analyzed by mass spectrometry, confirming the presence of proteins associated with insecticidal activity. In conclusion, it is hypothesized that $S$. campanulata nectar has insecticidal effects and this activity is linked to the classes of pro-oxidant proteins or peptides present in its chemical composition.
\end{abstract}

(C) 2016 Elsevier B.V. All rights reserved.

\section{Introduction}

The search for compounds able to control and protect against plant pests and consequential diseases is one of the main challenges faced by the agricultural industry. Prior to pesticides, farmers solved their phytosanitary problems using natural insecticides extracted from plant leaves, bark, flowers or nectar. However, with the advance of agricultural technology these natural insect control practices have been abandoned. Conversely, the widespread use of pesticides has triggered countless phytosanitary problems,

Abbreviations: 2D-PAGE, two-dimensional polyacrylamide gel electrophoresis; AAPH, 2,2'-azobis (2-amidino-propane) hydrochloride; BSA, bovine serum albumin; BVA, biological variation analysis; PBS, phosphate buffered saline; SDS-PAGE, sodium dodecyl sulfate polyacrylamide gel electrophoresis; ROS, reactive oxygen species; TBARS, thiobarbituric acid reactive substances.

* Corresponding author.

E-mail addresses: valter.vhmds@gmail.com (V.H.M. Santos), regildo@unesp.assis.br (R.M.G. Silva). including the development of insecticide resistance, mortality of non-target species, ecosystem damage, and residual insecticide accumulation in foods with toxic effects on humans and other organisms (Hernández-Lambraño et al., 2014). In addition to phytosanitary problems, there is a considerable increase in acquisition costs and application of pesticides in affected crops (Tavares et al., 2009).

Insect pests are capable of evolving into biotypes that can adapt to new situations and overcome the effect of toxic materials or natural plant defenses, resulting in extensive destruction of field crops. Soybean is one of the most important crops in the world, covering approximately 32 million hectares in Brazil, but is constantly affected by insect pests (Conab, 2015), such as Anticarsia gemmatalis; Helicoverpa zea and Euschistus heros A. gemmatalis is the major soybean insect pest, occurring mainly in the growing regions of North and South America (Macrae et al., 2005). Substantial infestation of $A$. gemmatalis is responsible for high levels of defoliation and meristem damage (Crialesi-Legor et al., 2014). Larval stage $H$. zea is a major polyphagous agricultural pest, consuming a wide 
variety of crops, such as cotton, tomato, corn and soybean (ReayJones and Reisig, 2012). E. heros feeds on various plant structures, mainly fruits and immature seeds, affecting their quality, development and maturation (Timbó et al., 2014). Due to the number of soybean pests, companies working with the crop have supported studies to control insect pests, especially by genetic improvement, biological control or plant-derived insecticidal compounds (Santos et al., 2015).

Plants produce a great arsenal of compounds as a strategic defense mechanism against insects. These compounds may be involved in the normal development of plants or act exclusively in an insecticidal protection system (Ibanez et al., 2012). Natural chemical compounds are generally considered less harmful to human health and the environment and have less adverse effects caused by the uncontrolled application of agrochemicals (Vasconcelos et al., 2006). Many proteins have been tested for their repellent, deterrent, or lethal effects against insect pests (Carlini and Grossi-De-Sá, 2002; Vandenborre et al., 2011; Ibanez et al., 2012). Some of these proteins exert their insecticidal effect by oxidative mechanisms, forming reactive oxygen species (ROS) and free radicals in the insect digestive tract (Barbehenn et al., 2008). However, it is still unclear whether the toxic activity can be directly attributed to proteins or to the induction of oxidative stress.

The plants investigated to control insects and weeds are species with the potential capacity to produce substances from primary and/or secondary metabolism that affect the growth and development of herbivores (Rice, 1984). Within the group of primary metabolites with potential insecticide activity, there are a few notable classes of proteins, such as inhibitors of $\alpha$-amylase, lectins and proteinase inhibitors (Falco et al., 2001). These compounds can generate several injuries on contact with insects, such as the inhibition of carbohydrate catalytic enzymes in the digestive tract and modification of the growth rate and development of pests (Peumans and Van Damme, 1995; Iulek et al., 2000). Others studies have shown that ROS can be generated in response to these natural substances and cause severe injuries to the organism, leading to death. One of the best-known modes of action is by interaction with lipids in cell membranes and generation of a destructive process known as lipid peroxidation (Grant and Loake, 2000; Abdollahi et al., 2004).

Spathodea campanulata P. Beauv (Bignoneaceae), popularly known as African tulip tree, is native of West African tropical forests. It has been widely introduced as an ornamental plant in several regions of tropical America. In Brazil it is frequently used in urban forestry. Portugal-Araujo (1963) and Trigo and Santos (2000) reported the occurrence of different species of dead insects (bees, flies and ants) on flowers of an inflorescence of $S$. campanulata. Different authors suggest that the insecticidal action is related to the presence of toxic compounds present in the mucilage of flowers and young shoots that would be dissolved in the nectar, and are responsible for the insects death (AlarcónNoguera and Penieres-Carrillo, 2013; Queiroz et al., 2014; Franco et al., 2015). The presence of toxic compounds in the nectar is partially explained because the pollinators of this plant are birds, mainly hummingbirds, they in addition to consuming the nectar also feed on the dead insects present in the flowers, representing an extra attraction for the pollinators (Zaheer et al., 2011).

In this study, a possible oxidative, insecticidal activity associated with the natural compounds present in S. campanulata nectar was analyzed against insect pests of soybean. Additionally, the proteins present in the nectar were quantified and identified by electrophoresis (SDS-PAGE and 2D-PAGE) and mass spectrometry (MS).

\section{Materials and methods}

\subsection{Collection and preparation of nectar}

The nectar was collected in fully opened flowers from S. campanulata grown in the urban perimeter region of Bela Vista do Paraíso city, Paraná state $\left(23^{\circ} 00^{\prime} 57.3^{\prime \prime} \mathrm{S}, 51^{\circ} 11^{\prime} 28.4^{\prime \prime} \mathrm{W}\right)$, Brazil. Plants were randomly selected 7 days prior to collection and their inflorescences packed to protect them from wind, rain and herbivores. From nine plants, using a Pasteur pipette, approximately $0.5 \mathrm{~mL}$ of nectar per flower was harvested, totaling 40 flowers per individuals in the morning period. The period of collection was established after determination of sugars concentration by refractometry, establishing the period of greatest concentration throughout the day. The nectar samples were stored in plastic bottles refrigerated $\left(4^{\circ} \mathrm{C}\right)$ and taken to the laboratory. Soon after the nectars were collected (approximately $180 \mathrm{~mL}$ ), frozen and lyophilized, yielding $9.82 \mathrm{~g}$ of dried nectar.

\subsection{Gross nectar dialysis and denaturation}

Dialysis was performed in deionized water using a $25 \times 16 \mathrm{~mm}$ membrane (InLab, USA) with a $10 \mathrm{kDa}$ molecular weight cut-off, for $24 \mathrm{~h}$. After, the dialyzate was frozen and stored for insecticidal activity assays. Gross nectar was denatured at $80^{\circ} \mathrm{C}$ in a water bath, for approximately $20 \mathrm{~min}$.

\subsection{Insecticidal tests}

\subsubsection{Insecticidal activity against Euschistus heros (Fabr.)}

E. heros nymphs, in the 3rd-5th instar, were provided by the Agronomic Institute of Campinas (IAC) and were fed with Phaseolus vulgaris L. (jack bean) plants sprayed with gross nectar, dialyzate nectar or distilled water (control). After, 20 nymphs were put into polyethylene experimental units $(10 \times 11 \mathrm{~cm}$ boxes), with food (i.e. jack bean, as abovementioned) and kept under controlled luminosity ( $12 \mathrm{~h}$ light/dark photoperiods), temperature $\left(25 \pm 1^{\circ} \mathrm{C}\right)$ and humidity $(60 \pm 10 \%)$. The test was conducted in a randomized design with four replications for each of the experimental groups, including the control. Nymph mortality was assessed daily for up to 15 days. The experimental groups received $30 \mu \mathrm{L}$ of gross nectar or dialysate nectar and negative control $30 \mu \mathrm{L}$ of distilled water.

Percentage nymph mortality was calculated using the formula:

$\frac{\text { Number of nymphs dead }}{\text { Total number of nymphs }} \times 100$

\subsubsection{Insecticidal activity against Helicoverpa zea (Boddie) and} Anticarsia gemmatalis (Hübner)

Twenty caterpillars of $A$. gemmatalis and $H$. zea were randomly assigned to individual Petri dishes $(60 \times 15 \mathrm{~mm})$ and fed with the diet proposed by Greene et al. (1976) and Navarro (1987). The food was sprayed with gross nectar, dialyzate nectar or distilled water (control) prior to using as feed and replaced every 2 days. Insect mortality index was assessed every 2 days for up to 30 days. The experimental groups received $30 \mu \mathrm{L}$ of gross nectar or dialysate nectar and negative control $30 \mu \mathrm{L}$ of distilled water.

Percentage insect mortality was calculated using the formula:

Number of dead insectsTotal number of insects $\times 100$ 


\subsection{Oxidant tests}

\subsubsection{Albumin degradation oxidative test}

The albumin degradation oxidative test was adapted from the method of Hsieh et al. (2005). Briefly, bovine serum albumin (BSA) $(2 \mathrm{mg} / \mathrm{ml})$ was diluted in phosphate buffered saline (PBS) $(10 \mathrm{mM}$, $\mathrm{pH} 7.4)$ and incubated with $\mathrm{Cu}^{2+}(2 \mathrm{mM})$ at $37^{\circ} \mathrm{C}$ for $2 \mathrm{~d}$ in the presence of $500 \mu \mathrm{L}$ of gross nectar, denatured nectar, $5 \mathrm{mM}$ hydrogen peroxide solution (positive control) or BSA solution $(110 \mu \mathrm{g} / \mathrm{ml})$ in phosphate buffer (negative control), respectively. Electrophoresis was carried out by SDS-polyacrylamide (12\% acrylamide and a $5 \%$ stacking gel) gel electrophoresis (SDS-PAGE), according to established techniques (EnCor Biotechnology Inc , FL, USA). The oxidant activity was evaluated by comparing the treatments with the negative control (PBS + BSA).

\subsubsection{Evaluation of oxidation potential by thiobarbituric acid reactive substances (TBARS)}

A thiobarbituric acid reactive substances (TBARS) test was performed to quantify the level of lipid peroxidation, according to the method of Boligon et al. (2014). Egg yolks were homogenized (1\% $\mathrm{w} / \mathrm{v}$ ) in $50 \mathrm{mM}$ phosphate buffer ( $\mathrm{pH} 7.4$ ) and used as a lipid-rich substrate (Guimarães et al., 2010). The homogenate $(0.5 \mathrm{~mL})$ was then sonicated and added to $0.1 \mathrm{~mL}$ of gross nectar $(1 \%, 5 \%$ and $10 \%)$, denatured nectar $(1 \%, 5 \%$ and $10 \%)$ and $140 \mu \mathrm{g} \mathrm{mL}^{-1}$ of $6-$ hydroxy-2,5,7,8-tetramethylchroman-2-carboxylic acid i.e. Trolox (negative control), respectively. Lipid peroxidation was induced by adding $0.1 \mathrm{~mL}$ of 2,2'-azobis (2-amidino-propane) hydrochloride $(\mathrm{AAPH}, 0.12 \mathrm{M})$ (positive control) and the solutions subsequently incubated in a water bath at $37^{\circ} \mathrm{C}$ for $30 \mathrm{~min}$. After cooling, $0.5 \mathrm{~mL}$ of trichloroacetic acid (15\%) and $0.5 \mathrm{~mL}$ of thiobarbituric acid $(0.67 \%)$ were added and the mixture then heated at $97^{\circ} \mathrm{C}$ for $15 \mathrm{~min}$. $n$ Butanol $(1 \mathrm{~mL})$ was then added to each solution, centrifuged at $1200 \mathrm{rpm}$ for $10 \mathrm{~min}$, cooled and their respective absorbance values measured at $532 \mathrm{~nm}$. The results were expressed as a percentage of TBARS $\left(A_{\text {control }}-A_{\text {sample }} \times 100 / A_{\text {control }}\right)$, where $A_{\text {control }}$ : is the absorbance obtained with AAPH and $A_{\text {sample }}$ : is the absorbance of the treatment solutions and negative control, respectively.

\subsection{Protein characterization}

\subsubsection{Precipitation of the gross nectar}

For improved purification and concentration of the proteins, $1 \mathrm{~mL}$ of gross nectar was mixed with $4 \mathrm{~mL}$ of $80 \%$ acetone, vortexed and stored in a refrigerator at $3^{\circ} \mathrm{C}$ for $2 \mathrm{~h}$ (Lanças et al., 2003). The supernatant was dried under nitrogen flow, resuspended in PBS ( $10 \mathrm{mM}, \mathrm{pH} 7.4$ ) and stored at $-10^{\circ} \mathrm{C}$.

\subsubsection{Protein content}

Quantification of the protein in samples of crude, dialysed, lyophilized and precipitated nectar samples was performed to evaluate the presence of protein content after each processing of the nectar, used the Bradford method (1976) and BSA as standard, protein values were obtained in $\mathrm{mg}$ BSA per $\mathrm{ml}$ of PBS buffer $(10 \mathrm{mM}$, $\mathrm{pH} 7.4)$.

\subsubsection{Polyacrylamide gel electrophoresis (SDS-PAGE)}

The protein composition of the dialyzed and precipitated samples was detected by SDS-PAGE, according to the method of Laemmli (1970), on 10\% separating gel and 3\% stacking gel. Prior to electrophoresis, the samples were solubilized in sample buffer (0.5 M Tris buffer, pH 6.8; $10 \%$ SDS; $\beta$-mercaptoethanol; glycerol; bromophenol blue and distilled water). An aliquot of each sample $(15 \mu \mathrm{L})$ was loaded onto the electrophoresis gel, which was run under constant voltage $(100 \mathrm{~V})$ at room temperature $\left(25^{\circ} \mathrm{C} \pm 2\right)$ for
$2 \mathrm{~h}$. The gel was subsequently stained with a solution of Coomassie Brilliant Blue R-250.

\subsubsection{Two-dimensional electrophoresis (2D-PAGE)}

The proteins in lyophilized nectar samples were investigated by 2D-PAGE due to the high protein concentration in these samples and the improved resolution of this method compared to SDSPAGE. Aliquots of nectar $(212 \mathrm{mg}$ ) were resuspended in phosphate buffer $(0,005 \mathrm{M}$; pH8) and the total protein concentration then determined using the ToPA kit (Biosciences, PA, USA). Then, $120 \mu \mathrm{g}$ of total protein was transferred to test tubes and precipitated using the ToPREP kit (Biosciences, PA, USA) to remove sugars and other interfering substances. The precipitated sample was resuspended in $50 \mu \mathrm{L}$ ToPI-DIGE buffer (Biosciences, PA, USA) for 2D-PAGE. The first dimension was performed using a $24 \mathrm{~cm}$ long IPG (immobilized pH gradient) strip of $\mathrm{pH} 3-10$, at $30 \mathrm{~V}$. Then, proteins were focused at $8000 \mathrm{~V}$ permitting a total of $65000 \mathrm{~V} / \mathrm{h}$. After equilibration of the IPG strips with reduction the proteins were separated in the second dimension using a $12.5 \%$ polyacrylamide gel of $24 \times 20 \mathrm{~cm}$ for approximately $4 \mathrm{~h}$. The gel was fixed overnight and stained with Coomassie Brilliant Blue R-250. The gel was then scanned with a Typhoon digital imager. The image was analyzed using biological variation analysis (BVA), a module of the DeCyder software v 6.5.

\subsubsection{Protein digestion and mass spectrometry analysis}

After analyzing the 2D gels and selecting the main representative spots by DeCyder BVA software, 13 spots were excised manually (approximately $1 \mathrm{~mm}^{2}$ ) with a plastic plunger. The spots were then digested with trypsin and cleaned with Zip Tip C18 (Millipore, Bedford, USA) for MS analysis, according to the method of Silveira et al. (2008).

After obtaining the digested and purified samples, the peptides were loaded onto an LC column using an autosampler, and eluted using a linear acetonitrile (Sigma, St Louis, USA) gradient from 2 to $30 \%$ over $60 \mathrm{~min}$, then high and low organic washes for another 30 min into an LTQ XL mass spectrometer (Thermo Scientific, Germering, DE) via a nanospray source. The spray voltage was set to $1.8 \mathrm{kV}$ and the ion transfer capillary set at $180^{\circ} \mathrm{C}$. A data-dependent top-5 method was used, which involved a full MS scan from $m / z$ 400-1500, prior to MS/MS scans of the five most abundant ions. Each ion detectable in the spectrum was further selected for CID to identify the peptide.

Raw data files were searched against the most recent databases from UniProt (http://www.uniprot.org/) using Proteome Discoverer 1.4 (Thermo Scientific) and the SEQUEST HT search algorithm. Oxidation (of Met) was used as a variable modification and the carbamidomethyl (of Cys) was used as a fixed modification. The fixed value PSM (peptide-spectrum match) algorithm was used as PSM validation in the database searches.

The Angiosperm (flowering plants) database was selected for the first search and returned the majority of the match with Vitis vinifera proteins. Therefore, the Vitis vinifera database was downloaded and a second search conducted.

\subsection{Statistical analysis}

Statistical analysis was performed using the Shapiro-Wilks normality test and the Levene homogeneity test. The data were normally distributed and the variances were homogeneous. Therefore, the data were analyzed using the parametric ANOVA and Tukey tests $(\alpha=0.05)$. These tests were performed using BioEstat 5.0 software. 
Table 1

Mortality index of Euschistus heros (Fabr.), Helicoverpa zea (Boddie) and Anticarsia gemmatalis (Hübner).

\begin{tabular}{llll}
\hline \multirow{2}{*}{ Treatments } & \multicolumn{2}{l}{ Mortality $^{\mathrm{a}}$} & \\
\cline { 2 - 4 } & E. heros & H. zea & A. gemmatalis \\
\hline Gross néctar & $12 \pm 3 \mathrm{a}$ & $16 \pm 2 \mathrm{a}$ & $10 \pm 1 \mathrm{a}$ \\
Dialysate nectar & $7 \pm 2 \mathrm{~b}$ & $11 \pm 2 \mathrm{~b}$ & $10 \pm 1 \mathrm{a}$ \\
Control & $4 \pm 2 \mathrm{c}$ & $5 \pm 2 \mathrm{c}$ & $4 \pm 2 \mathrm{~b}$ \\
\hline
\end{tabular}

a Data are expressed as the mean of three replicates $\pm S D,(n=20)$. Means within a column followed by the same letter are not significantly different (Tukey's test, $\mathrm{p}<0.05$ ).

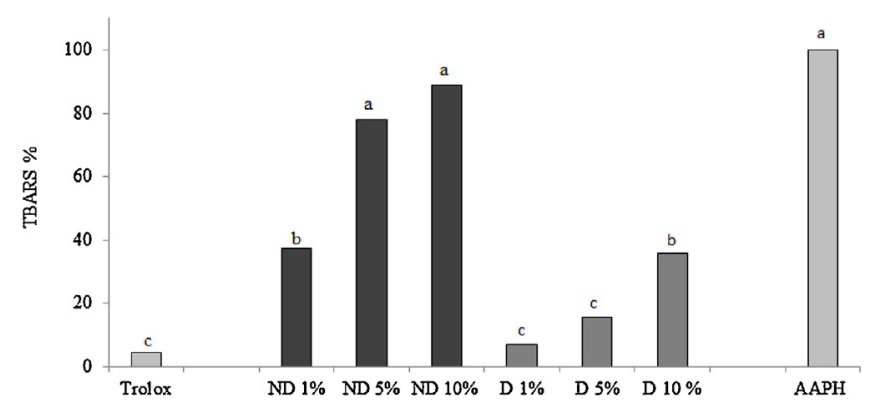

Fig. 1. \% TBARS oxidation compared to a positive control (AAPH). Means with the same letter do not differ significantly by Tukey's test $(\alpha=0.05)$. (ND $=$ non-denatured nect and $\mathrm{D}=$ denatured nect).

\section{Results}

\subsection{Protein content}

The total protein present in the samples was calculated using a BSA standard curve $\left(y=0.012+0.027 x ; R^{2}=0.991\right)$. The gross nectar and dialyzed nectar had a total protein content of $95 \mu \mathrm{g} \mathrm{mL}-1$ and $10 \mu \mathrm{g} \mathrm{mL}^{-1}$, respectively.

\subsection{Insecticidal tests}

Insecticide tests showed toxic activity against groups treated with gross or dialyzed nectar, independent of the insect species used (Table 1 ). In assays conducted with $E$. heros the gross nectar showed a mortality of $60 \%$, the dialyzate nectar, $35 \%$ and the control, $20 \%$. Similar results were observed for $\mathrm{H}$. zea; gross nectar presented the highest mortality (80\%), followed by dialyzate nectar (55\%) and control (25\%). A. gemmatalis showed no difference between gross and dialyzate nectar (50\% mortality for both). However, both nectar samples were efficient compared to the control (20\%).

\subsection{Evaluation of oxidation potential by thiobarbituric acid reactive species (TBARS)}

There was a tendency for non-denatured nectar (5 and 10\%) of S. campanulata to show high levels of oxidative activity, by TBARS (Fig. 1). In contrast, no significant oxidative activity was observed using different denatured nectar content. The highest amount (D $10 \%$ ) presented a similar oxidation percentage as the lowest percentage of non-denatured nectar (ND 1\%).

\subsection{Albumin degradation oxidative test}

Oxidative analysis of albumin degradation in a polyacrylamide gel showed high oxidant activity in non-denatured nectar (Fig. 2). This activity was observed by comparing the bands for the treated group $(\mathrm{BSA}+\mathrm{Cu}+$ non-denatured nectar) with the positive control $(\mathrm{BSA}+\mathrm{Cu}+$ hydrogen peroxide) and $\mathrm{BSA}+\mathrm{Cu}$. Denatured

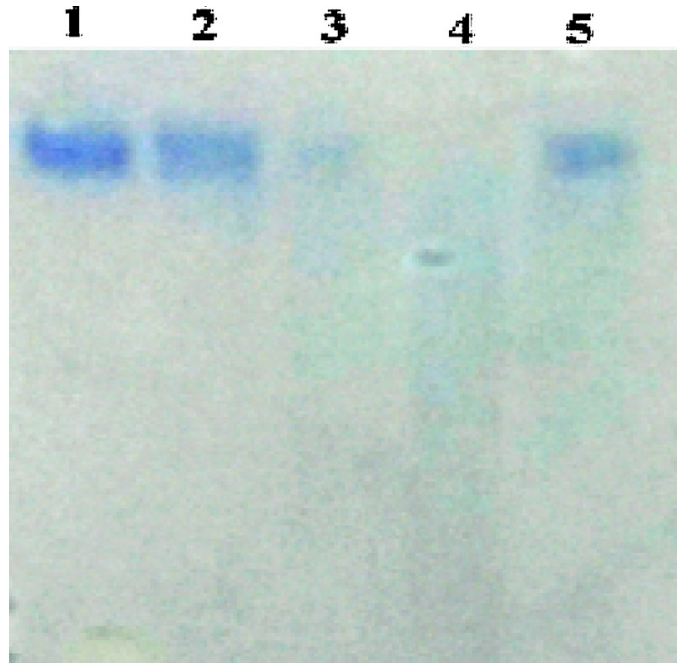

Fig. 2. Oxidative analysis of albumin degradation in a polyacrylamide gel stained by Coomassie Brilliant Blue. 1-BSA (negative control); 2-BSA + Cu; 3 $\mathrm{BSA}+\mathrm{Cu}+$ hydrogen peroxide (positive control); 4-BSA + $\mathrm{Cu}+$ non-denatured nectar; $5-\mathrm{BSA}+\mathrm{Cu}+$ denatured nectar.

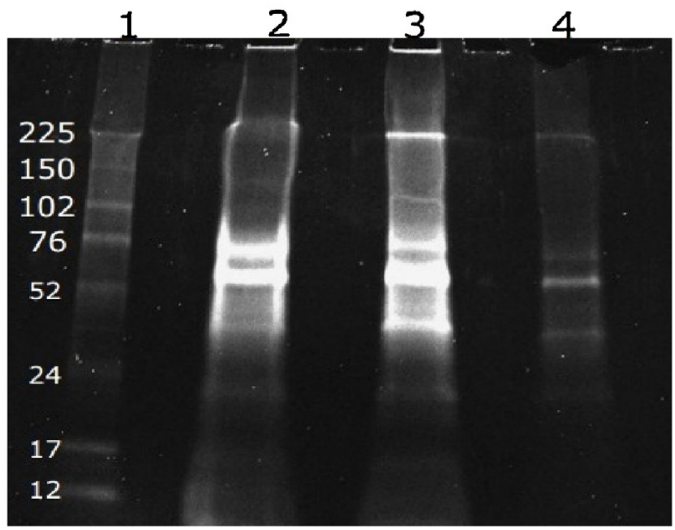

Fig. 3. Electrophoretic analysis of nectar in the polyacrylamide gel stained with Coomassie Brilliant Blue R-250. 1-molecular marker (kDa); 2-lyophilized nectar; 3-precipitated nectar; 4-gross nectar.

nectar $+\mathrm{BSA}+\mathrm{Cu}$ presented a lower oxidative activity compared to non-denatured nectar.

\subsection{Polyacrylamide gel electrophoresis (SDS-PAGE)}

Prior to SDS-PAGE, the total protein content of gross, lyophilized and precipitated nectar was determined as 109.2, 784.4 and $412.7 \mu \mathrm{g} \mathrm{mL}^{-1}$, respectively. SDS-PAGE analysis (Fig. 3) showed that the various nectar preparations had comparable protein profiles. Three major bands with molecular masses of approximately $38 \mathrm{kDa}, 60 \mathrm{kDa}, 76 \mathrm{kDa}$ and a more intense band at $225 \mathrm{kDa}$ were present in all samples. Based on the results, lyophilized nectar was investigated by 2D-PAGE. The dialyzed nectar was not quantified by SDS-PAGE because it presented low concentration in the determination of total proteins (Section 3.1).

\subsection{Two-dimensional electrophoresis (2D-PAGE)}

In 2D-PAGE, each identified spot could be considered a possible protein candidate. According to the DeCyder BVA software, 51 spots were detected (Fig. 4). Despite a large number of spots detected, most of the spots were probably artifacts and did not represent proteins. From the 51 spots annotated by the software, 13 


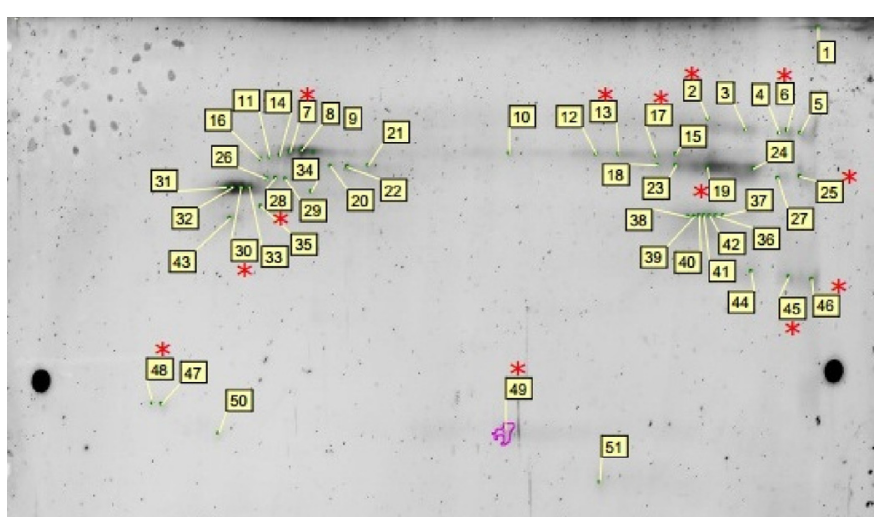

Fig. 4. All 51 spots assigned as possible protein candidates detected by DeCyder BVA software. Spots (red marks) were further analyzed by mass spectrometry. (For interpretation of the references to colour in this figure legend, the reader is referred to the web version of this article.)

spots (marked red in Fig. 4) were compatible with proteins and subsequently submitted to MS analysis.

\subsection{Mass spectrometry analysis}

From the 13 spots selected in the 2D-PAGE, peptide sequences were identified according to their degree of similarity to sequences in the UniProt database. After peptide identification, those related to insecticidal activity were selected (Table 2). Due to the scarcity of proteomic information concerning the species investigated in this study, it was not viable to isolate the proteins with insecticidal activity by selective fractionation because the protein content of the nectar had not been previously reported. The complete list of peptides found in the 13 spots obtained by 2D-PAGE is presented in the supplementary material.

\section{Discussion}

Plants have evolved sophisticated defense mechanisms against insects and associated diseases. Nectar, leaves, bark and seeds may accumulate defensive compounds that confer resistance against phytophagous predators and infection by microorganisms. The insecticide tests with $E$. heros, $H$. zea and A. gemmatalis demonstrated a toxic effect of gross and dialyzed nectar against all groups. A similar effect has been observed with other insects, such as Plebeia droryana, Tetragonisca angustula, Scaptotrigona postica, Trigona spinipes and Friesella schrottky, present in the inflorescences of S. campanulata (Nogueira-Neto, 1997). In other research related to nectar toxicity, Portugal-Araujo (1963) found 200 dead insects, including ants, bees and flies, in a single inflorescence of $S$. campanulata. In addition to this, scientific studies carried out with different parts of this species (bark, leaves and flowers) only demonstrated the presence of phytochemical compounds of secondary metabolism, mainly with pharmacological activity (Niyonzima et al., 1999). Regarding to the insecticidal activity, although demonstraded in different works, there is no scientific information on the compounds responsible for this activity.

Characterization of plant constituents is essential to the management of pest control, as compounds associated with secondary metabolism and/or classes of peptides and proteins may be responsible for insecticidal effects. These compounds are frequently associated with protection against herbivores, a characteristic described in many plant species producing nectar (Adler, 2000). Cintra et al. (2005) hypothesized that plant-insect interactions, such as between flower and pollinators (nectar action), should

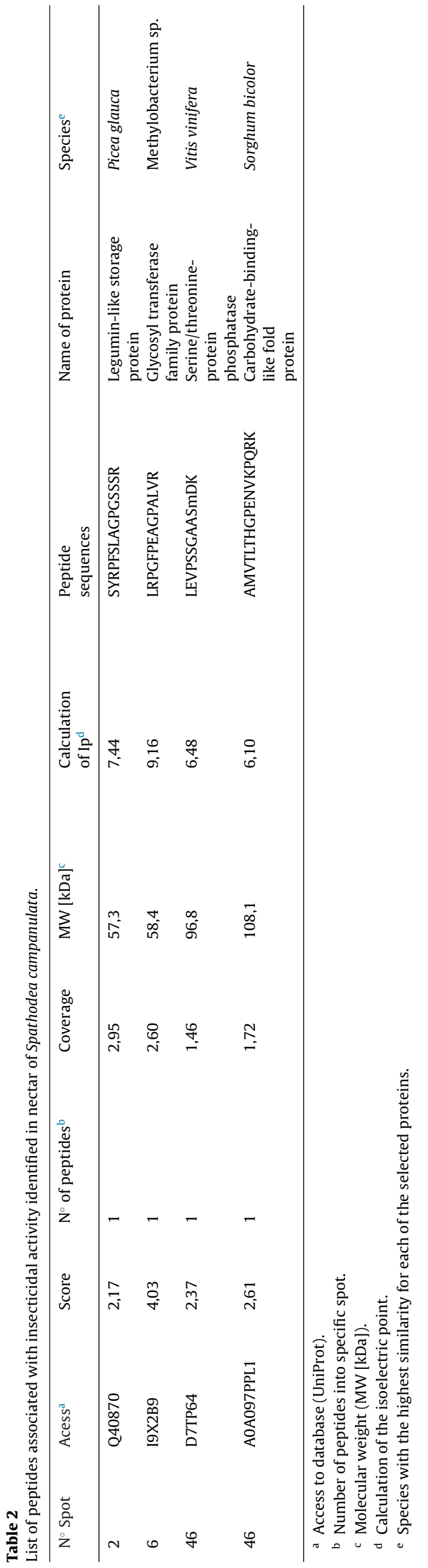


be studied together and not separately, as many particularities of selection occur in both interactions.

Chemical compounds (secondary metabolites and some classes of proteins) with insecticide effect can confer biochemical protection to plants by inducing the production of ROS that can act negatively on insect metabolism when they come in contact (Doke et al., 1996; Seo et al., 2013). In this study, the results obtained by TBARS quantification and oxidative analysis of albumin degradation suggested that the insecticide action may be due to chemical compounds in the nectar of $S$. campanulata. This active compound may be a protein because denatured nectar was less effective than non-denatured nectar in both tests. Grant and Loake (2000) reported that ROS present in plant tissues may lead to the death of plant pathogens by mechanisms that affect nutrient absorption, respiratory activity and synthesis of proteins and enzymes, among other metabolic functions.

Others studies that support the idea of nectars with insecticidal proteins were carried out with Nicotiana attenuate (Naqvi et al., 2005). Seo et al. (2013), studying the nectar of this same species, showed that despite the presence of large amounts of sugars such as sucrose, glucose and fructose, they also contained several classes of proteins. Moghaddam et al. (2016) suggested that nectarines are not involved in attracting pollinators but instead involved in defense against the proliferation of microorganisms in the nectar, mainly by production of strong oxidants, such as hydrogen peroxide $\left(\mathrm{H}_{2} \mathrm{O}_{2}\right)$, hydroxyl radical $\left(\mathrm{OH}^{\bullet}\right)$, singlet oxygen $\left({ }^{1} \mathrm{O}_{2}\right)$ and superoxide radical $\left(\mathrm{O}_{2}{ }^{\bullet-}\right)$.

The biochemical defense performed by proteins may occur directly or indirectly (Carozzi and Koziel, 1997; Falco et al., 2001). The direct action is performed by the protein itself without activation of other pathways, whereas proteins with indirect action are able to produce or induce the formation of others substances with bioactive activity (Ferreira-da-Silva et al., 2000; Abdollahi et al., 2004). Lectin is an interesting class of protein that can induce an insecticide effect when present in the chemical composition of the plant (Sales et al., 2000; Pereira et al., 2015). This carbohydratebinding protein is considered an important metabolite and can act in defense mechanisms against insects and pathogens, causing degenerative effects on epithelial cells of the digestive system. Thus, they are able to paralyze insect digestion and cause food deprivation and death (Santos et al., 2009; Tajne et al., 2014). Lectin may be considered a legumin-like storage protein as it is one of the most abundant compounds in legume seeds (Sales et al., 2000). In the current work, the MS analysis revealed the presence of both classes of proteins, carbohydrate-binding-like and leguminlike storage proteins, which may be associated with the insecticidal activity of the nectar.

Proteins that may be involved indirectly in the insecticidal effect of $S$. campanulata nectar, are the glycosyl transferase family proteins and serine-threonine-protein phosphatase (Table 2). The glycosyl transferase family are enzymes that might be involved in the biosynthesis of secondary compounds with insecticidal activity (Ferreyra et al., 2013). An example is maysin, a C-glycosyl flavone predominant in silk tissues of some maize varieties and a natural insecticide against the corn earworm $\mathrm{H}$. zea (McMullen et al., 2004). Nevertheless, C-glycosyl flavonoids identified in cucumber leaves were shown to act as phytoalexins in defense against powdery mildew fungi (McNally et al., 2003). In the instance of serine-threonine-protein phosphatase, this enzyme is involved in the biosynthesis of a phytohormone with insecticidal effect, the brassinosteroid. In tests with insects, the effects of brassinosteroid on cell cultures in vitro and whole larvae in vivo (Sobek et al., 1993; Charrois et al., 1996) and in delayed development of two holometabolous insects from different fly species (Phornia terranovae, Calliphora vicina) has been reported, revealing a significant antagonistic activity (Richter and Koolman, 1991). Sci- entists believe its insecticidal activity is based on interference in the various ecdysteroid dependent steps, resulting in disruption or abnormal growth and development of the target pest, helping to overcome resistance to insecticides (Smagghe et al., 2002; Davison et al., 2003).

\section{Conclusion}

The present study described the peptide composition investigation of the nectar of S. campanulata which led to the identification of presence of proteins with insecticidal activity against insect pests of soybean. This action may be promoted by proteins or peptides with pro-oxidant activity that directly or indirectly affect insects. The present preliminary study suggests that $S$. campanulata could have potential as natural insecticide that could be employed in developing new insecticides types.

\section{Acknowledgements}

This work was supported by Fundação de Amparo à Pesquisa do Estado de São Paulo (FAPESP, 2012/24440-7) and Conselho Nacional de Desenvolvimento Científico e Tecnológico (CNPq, 306151/2012-0).

\section{Appendix A. Supplementary data}

Supplementary data associated with this article can be found, in the online version, at http://dx.doi.org/10.1016/j.indcrop.2016.12. 025 .

\section{References}

Abdollahi, M., Ranjbar, A., Shadnia, S., Nikfar, S., Rezaie, A., 2004. Pesticides and oxidative stress: a review. Med. Sci. Monit. 10, 141-147.

Adler, L.S., 2000. Alkaloid uptake increases fitness in a hemiparasitic plant via reduced herbivory and increased pollination. Am. Nat. 156, 92-99.

Alarcón-Noguera, R., Penieres-Carrillo, G., 2013. In vitro evaluation of African tulip (Spathodea campanulata B.) flowers and leaves extracts on berry borer of coffee (Hypothenemus hampei F.). Tecnología en Marcha 26 (3), 39-49.

Barbehenn, R.V., Maben, R.E., Knoester, J.J., 2008. Linking phenolic oxidation in the midgut lumen with oxidative stress in the midgut tissues of a treefeeding caterpillar Malacosoma disstria (Lepidoptera: Lasiocampidae). Environ. Entomol. 37, 1113-1118.

Boligon, A.A., Machado, M.M., Athayde, M.L., 2014. Technical evaluation of antioxidant activity. Med. Chem. 4 (7), 517-522.

Bradford, M.M., 1976. A rapid and sensitive method for the quantitation of microgram quantities of protein utilising the principal of protein-dye binding. Anal. Biochem. 72, 248-254.

Carlini, C.R., Grossi-De-Sá, M.F., 2002. Plant toxic proteins with insecticidal properties: a rewiew on their potentialities as bioinsecticides. Toxicon 40, 1515-1539.

Carozzi, N.B., Koziel, M.G., 1997. Advances in Insect Control: the Role of Transgenic Plants. Taylor \& Francis, London.

Charrois, G.J.R., Mao, H., Kaufman, W.R., 1996. Impact on salivary gland degeneration by putative ecdysteroid antagonists and agonists in the Ixodid Tick Amblyomma hebraeum. Pestic. Biochem. Physiol. 55, 140-149.

Cintra, P., Malaspina, O., Bueno, O.C., Petacci, F., Fernandes, J.B., Vieira, P.C., Silva, M.F.G.F., 2005. Oral toxicity of chemical substances found in Dimorphandra mollis (Caesalpiniaceae) against honeybees (Apis mellifera) (Hymenoptera: Apidae). Sociobiol 45, 141-149.

Conab - Companhia Nacional de abastecimento, 2015. Séries históricas relativas às safras de área plantada, produtividade e produção brasileira (http://www. conab.gov.br/. Access: 31 July 2015).

Crialesi-Legor, P.C.B., Davolos, C.C., Lemes, A.R.N., Marucci, S.C., Lemos, M.V.F., Fernandes, O.A., Desidério, J.A., 2014. Interação de proteínas Cry1 e Vip3A de Bacillus thuringiensis para controle de lepidópteros praga. Pesq. Agropec. Bras. 49, 79-87.

Davison, G.P., Restrepo, R., Martínez, G., Coll, F., León, O.S., 2003. Effects of a brassinosteroid analogue to mosquito larvae. Ecotoxicol. Environ. Saf. 56 419-424.

Doke, N., Miura, Y., Sanchez, L.M., Park, H.J., Noritake, T., Yoshioka, H., Kwakita, K., 1996. The oxidative burst protects plants against pathogen attack: mechanism and role as an emergency signal for plant bio-defence - a review. Gene 179, 45-51.

Falco, M.C., Marbach, P.A.S., Pompermayer, R., Lopes, F.C.C., Silva-Filho, M.C., 2001. Mechanism of sugarcane response to herbivory. Genet. Mol. Biol. 24, 113-122. 
Ferreira-da-Silva, C.T., Gombarovits, M.E., Masuda, H., Oliveira, C.M., Carlini, C.R 2000. Proteolytic activation of canatoxin, a plant toxic protein, by insect cathepsin-like enzymes. Arch. Insect Biochem. Physiol. 44, 162-171.

Ferreyra, M.L.F., Rodriguez, E., Casas, M.I., Labadie, G., Grotewold, E., Casati, P., 2013. Identification of a bifunctional maize C- and O-glucosyltransferase. J. Biol. Chem. 1, 1-16.

Franco, D.P., Guerreiro, J.C., Ruiz, M.G., Silva, R.M.G., 2015. Evaluation of insecticide potential of Spathodea campanulata (Bignoniaceae) nectar on Sitophilus zeamais (Coleoptera: Curculionidae). Colomb. J. Entomol. 41 (1), 63-67.

Grant, J.J., Loake, G.J., 2000. Role of reactive oxygen intermediates and cognate redox signaling in disease resistance. Plant Physiol. 124, 21-30.

Greene, G.L., Leppla, N.C., Dickerson, W.A., 1976. Velvetbean caterpillar: a rearing procedure and artificial medium. J. Econ. Entomol. 69, 487-488.

Guimarães, A.G., Oliveira, G.F., Melo, M.S., Cavalcanti, S.C., Antoniolli, A.R., Bonjardim, L.R., Silva, F.A., Santos, J.P., Rocha, R.F., Moreira, J.C., Araújo, A.A., Gelain, D.P., Quintans-Júnior, L.J., 2010. Bioassay-guided evaluation of antioxidant and antinociceptive activities of carvacrol. Basic Clin. Pharmacol. 107, 949-957.

Hernández-Lambraño, R., Caballero-Gallardo, K., Olivero-Verbel, J., 2014. Toxicity and antifeedant activity of essential oils from three aromatic plants grown in Colombia against Euprosterna elaeasa and Acharia fusca (Lepidoptera: Limacodidae). Asian Pac. J. Trop. Biomed. 4, 695-700.

Hsieh, C.L., Lin, Y.C., Ko, W.S., Peng, C.H., Huang, C.N., Peng, R.Y., 2005. Inhibitory effect of some selected nutraceutic herbs on LDL glycation induced by glucose and glyoxal. J. Ethnopharmacol. 102, 357-363.

Ibanez, S., Gallet, C., Després, L., 2012. Plant insecticidal toxins in ecological networks. Toxins 4, 228-243.

Iulek, J., Franco, O.L., Silva, M., Slivinski, C.T., Bloch Jr., C., Rigden, D.J., Grossi-de-Sá, M.F., 2000. Purification, biochemical characterization and partial primary structure of a new a-amylase inhibitor of common bean. Entomol. Exp. Appl. 79, 309-315

Laemmli, U.K., 1970. Cleavage of structural proteins during the assembly of the head of bacteriophage T4. Nature 227, 680-685.

Lanças, F.M., Silva, J.C.R., Bicudo, R.C., Neto, M.B., 2003. A química analítica no proteoma. Rev. Anal. 6, 60-67.

Macrae, T.C., Baur, M.E., Boethel, D.J., Fitzpatrick, B.J., Gao, A.G., Gamundi, J.C., Harrison, L.A., Kabuye, V.T., Mcpherson, R.M., Miklos, J.A., 2005. Laboratory and field evaluations of transgenic soybean exhibiting high-dose expression of a synthetic Bacillus thuringiensis cry1 A gene for control of Lepidoptera. J. Econ. Entomol. 98, 577-587.

McMullen, M.D., Kross, H., Snook, M.E., Cortes-Cruz, M., Houchins, K.E., Musket, T.A., Coe, E.H.Jr., 2004. Salmon silk genes contribute to the elucidation of the flavone pathway in maize (Zea mays L.). J. Hered. 95, 225-233.

McNally, D.J., Wurms, K.V., Labbe, C., Quideau, S., Belanger, R.R., 2003. Complex C-glycosyl flavonoid phytoalexins from Cucumis sativus. J. Nat. Prod. 66, 1280-1283.

Moghaddam, M.R.B., Vilcinskas, A., Rahnamaeian, M., 2016. Cooperative interaction of antimicrobial peptides with the interrelated immune pathways in plants. Mol. Plant Pathol. 17, 464-471.

Naqvi, S.M.S., Harper, A., Carter, C., Ren, G., Guirgis, A., York, W.S., Thornburg, R.W. 2005. Nectarin IV, a potent endoglucanase inhibitor secreted into the nectar o ornamental tobacco plants. Isolation, cloning, and characterization. Plant Physiol. 139, 1389-1400.

Navarro, R.V., 1987. Comportamiento de emergencia y reproduccion del gusano del jojoto (Heliothis zea Boddie). Agron. Trop. 37, 55-61.

Niyonzima, G., Laekernan, G., Witvrouw, M., Van Poel, B., Pieters, L.D., Paper Clercq, E.D., Franz Vlierinck, G.A.J., 1999. Hypoglycemic anticomplement and anti-HIV activities of Spathodea campanulata stem barkm. Phytomedicine 6 (1), 45-49.

Nogueira-Neto, P., 1997. Vida e criação das abelhas indígenas sem ferrão, 1st ed. Nogueirapis, São Paulo.

Pereira, P.R., Winter, H.C., Verícimo, M.A., Meagher, J.L., Stuckey, J.A., Goldstein, I.J. Paschoalin, V.M., Silva, J.T., 2015. Structural analysis and binding properties of isoforms of tarin, the GNA-related lectin from Colocasia esculenta. Biochim. Biophys. Acta 1854, 20-30.
Peumans, W.J., Van Damme, E.J.M., 1995. Lectins as plant defense proteins. Plant Physiol. 109, 347-352.

Portugal-Araujo, V., 1963. O perigo de dispersão da tulipeira do gabão (Spathoded campanulata Beauv.). Chác. Quint. 107, 562-563.

Queiroz, A.C.M., Contrera, F.A.L., Venturieri, G.C., 2014. The effect of toxic necta and pollen from Spathodea campanulata on the worker survival of Melipona fasciculata Smith and Melipona seminigra Friese, two Amazonian stingless bees (Hymenoptera: Apidae: Meliponini). Sociobiology 61 (4), 536-540.

Reay-Jones, F.P.F., Reisig, D.D., 2012. Impact of corn earworm injury on yield of transgenic corn producing Bt toxins in the Carolinas. J. Econ. Entomol. 3, 1101-1109.

Rice, E.L., 1984. Allelopathy, 2nd ed. Academic Press, Orlando.

Richter, K., Koolman, J., 1991. Antiecdysteroid effects of brassinosteroids in insects. In: Cutler, H.G., Yokota, T., Adam, G. (Eds.), Brassinosteroids: Chemistry, Bioactivity and Applications. ACS Symposium 474. American Chemical Society, Washington DC

Sales, M.P., Gerhardt, I.R., Grossi-de-As, M.F., Xavier-Filho, J., 2000. Do legume storage proteins play a role in defending seeds against bruchids? Plant Physiol. $124,515-522$

Santos, A.F.S., Luz, L.A., Argolo, A.C.C., Teixeira, J.A., Paiva, P.M.G., Coelho, L.C.B.B., 2009. Isolation of a seed coagulant Moringa oleifera lectin. Process Biochem. 44 504-508.

Santos, V.H.M., Daneluzzi, G.S., Silva, L.P., Silva, R.M.G., 2015. Evaluation of allelopathic potential of leaf extract of Kielmeyera coriacea on Lactuca sativa L. Biosci. J. 31, 259-267.

Seo, P.J., Wielsch, N., Kessler, D., Svatoš, A., Park, C.M., Baldwin, I.T., Kim, S.G., 2013. Natural variation in floral nectar proteins of two Nicotiana attenuata accessions. BMC Plant Biol. 13, 1-12.

Silveira, V., Santa-Catarina, C., Balbuena, T.S., Moraes, F.M.S., Ricart, C.A.O., Sousa M.V., Guerra, M.P., Handro, W., Floh, E.S.I.S., 2008. Endogenous abscisic acid and protein contents during seed development of Araucaria angustifólia. Biol. Plant 52, 101-104.

Smagghe, G., Decombel, L., Carton, B., Voigt, B., Adam, G., Tirry, L., 2002. Action of brassinosteroids in the cotton leafworm Spodoptera littoralis. Insect Biochem. Mol. Biol. 32, 199-204.

Sobek, L., Bohm, G.A., Penzlin, H., 1993. Ecdysteroid receptors in last instar larvae of the wax moth Galleria mellonella L. Insect Biochem. Mol. Biol. 23, 125-129.

Tajne, S., Boddupally, D., Sadumpati, V., Vudem, D.R., Khareedu, V.R., 2014. Synthetic fusion-protein containing domains of Bt Cry1 Ac and Allium sativum lectin (ASAL) conferred enhanced insecticidal activity against major lepidopteran pests. J. Biotechnol. 171, 71-75

Tavares, W.S., Cruz, I., Petacci, F., Assis Júnior, S.L., Freitas, S.S., Zanuncio, J.C., Serrão, J.E., 2009. Potential use of Asteraceae extracts to control Spodopterd frugiperda (Lepidoptera: Noctuidae) and selectivity to their parasitoids Trichogramma pretiosum (Hymenoptera: Trichogrammatidae) and Telenomus remus (Hymenoptera: Scelionidae). Ind. Crop Prod. 31, 384-388.

Timbó, R.V., Lima-Herms, M., Silva, L.P., Mehta, A., Moares, M.C.B., Paula, D.P., 2014 Biochemical Aspects of the soybean response to herbivory injury by the brown stink bug Euschistus heros (Hemiptera: Pentatomidae). PLoS One 9, 1-10.

Trigo, J.R., Santos, W., 2000. Insect mortality in Spathodea campanulata Beauv. (Bignoniaceae) flowers. Rev. Bras. Biol. 60, 537-538.

Vandenborre, G., Smagghe, G., Van Damme, E.J., 2011. Plant lectins as defense proteins against phytophagous insects. Phytochemistry 72, 1538-1550.

Vasconcelos, G.J.N., Godin Junior, M.G.C., Barros, R., 2006. Aqueous extracts of Leucaena leucocephala and Sterculia foetida to the control of Bemisia tabaci biotype B (Hemiptera: Aleyrodidae). Ciênc. Rural 36, 1353-1359.

Zaheer, Z., Paithankar, A.P., Deshpande, S.D., Khan, S., 2011. Optimization of extraction process and phytochemical investigations of Spathodea campanulata flowers. Afr. J. Pharm. Pharmacol. 5 (20), 2226-2231. 